\title{
Fletcher's Versification
}

\section{Marina Tarlinskaja*}

\begin{abstract}
The essay deals with Fletcher's versification compared to his contemporaries and co-authors. Fletcher had the most feminine endings compared to other playwrights, more compound feminine endings, and more heavy (stressed) feminine endings. He had few run-on lines: run-on lines and compound feminine endings are in reverse proportion. The main features outlined in the paper are the distribution of stressing and strong syntactic breaks in the line, types of line endings, and the syntactic and semantic function of enclitic micro-phrases. Fletcher's verse had undergone an evolution, from Bonduca and Valentinian (1610-13) to The Island Princess (1621-23), e. g. the changed place of strong syntactic breaks. Analysis of Massinger's verse confirmed Oras's impression that it was prose-like: Massinger often squeezed two syllables into the same metrical slot; he had little hemistich segmentation; and he often divided his lines syntactically; the second part of the divided line ran-over onto the next line, thus effacing the division of his verse into lines. Unlike Shakespeare's enjambments, which are composed with masculine endings and with an unstressed monosyllabic grammatical word placed on position 10, Massinger's syntactic breaks in midline and run-on lines occur with compound light feminine endings.
\end{abstract}

Keywords: meter, rhythm, syllabic position, enclitics, proclitics, line endings, enjambment.

\section{Introduction}

This essay is about the versification of John Fletcher's plays analyzed linguistically. We compare Fletcher's verse style with that of his predecessors and contemporaries, including co-authors. The results can be used for the attribution of scenes in collaborative plays.

Verse form is a significant feature of English Renaissance drama, and its variations show the evolution of the line stressing, their syntactic composition, the line endings, and other features of verse. Its analysis differentiates the styles of individual authors. We will look at Fletcher's versification in his solo plays and in collaborations with other playwrights. We shall observe the correlation between line endings and enjambments. Scholars have often neglected the features of

Author’s address: Marina Tarlinskaja, Department of Linguistics, University of Washington, Seattle, Box 354340 Seattle, WA 98195-4340. E-mail: marinat@uw.edu. 
versification; when one reads their critical works, it is not clear in what form the analyzed texts were composed - as prose or as verse. And does it matter? Yes, it does. Playwrights took special pains to compose their texts in verse, though plays were often written in a hurry, and sometimes by two or more authors.

Plays were not considered works of art. In his poem A Session of the Poets, John Suckling depicts a conference in which poets argue who deserves a laurel wreath, and Ben Jonson "told them plainly he deserved the bays, | For his were called Works, while others were but plays". And yet, the playwrights invested time and effort to compose their plays in metrical verse. The verse was iambic pentameter; this verse form had become traditional since 1561, when Gorboduc, the first tragedy in iambic pentameter, was composed. The verse form gave clues to the audience, so that the public not only recognized the genres of tragedy vs. comedy, but probably also heard the differences between the utterances of different character types (Tarlinskaja 1984). When commoners spoke in prose and noble heroes discoursed in verse, the opposition emphasized the social status of the characters. The difference between heroes and villains was also reflected in the structure of their utterances, e. g. Othello of the first act vs. Iago (Tarlinskaja 1987). Variations of the meter can add to the text semantics.

Rhythmical structure of separate lines also began to add to the meaning of the text: poets had learned to create rhythmical italics (Tarlinskaja 2014: Appendix A). Rhythmical italics are deviations from the iambic meter used to emphasize the meaning, e. g. "Claps her pale cheek, till clapping makes it red" (Shakespeare, Venus and Adonis, 469) instead of something smoothly iambic: "He clapped her cheek". The act of clapping is emphasized by accentual deviations on syllables 1-2-3 (W-S-W). ${ }^{1}$ The verb on the first syllabic position (W) is the most important component of rhythmical italics. There are three times more verbs than other parts of speech within rhythmical italics, while in the text outside the italics the most frequent part of speech is the noun (Tarlinskaja 2014: 275). Within rhythmical italics, verbs of violent action (clap, pierce, beat, rush) are seven times more frequent than neutral verbs (sit, glance, think, sleep), while in the rest of the text, verbs of action are as frequent as neutral verbs. Rhythmical italics became a stylistic device not unlike onomatopoeia: the sound emphasizes the sense.

Playwrights usually followed the canons of their epoch, and so did Shakespeare (see Tables 1-3). As the periods changed, so did Shakespeare's

\footnotetext{
1 Iambic pentameter is a string of ten syllabic positions: weak, W, usually unstressed, and strong, S, usually stressed syllabic positions of the metrical line: WSWSWSWSWS(WW). The last two positions, the endings, called feminine and dactylic, are optional. They can bear a stress, usually with a weak phrasal accentuation, as in "The King is DEAD, then?"
} 
versification. Shakespeare's verse, as it changed during the 25 or so years of his writing career, helps to attribute a play to a chronological period. Fletcher's versification also changed with the times.

\section{Tests used in Verse Analyses: A Brief Outline}

\section{1.}

The First Test: Stressing. The first test is the stressing of syllables on every S (strong) and $\mathrm{W}$ (weak) syllabic position of the iambic meter. Several problems arise here. The main problem is the stressing of monosyllables (see Tarlinskaja 2014, Chapter 1). There are many nuances of stressing in speech; we recognize that, for example, adverbs so, too, and some other monosyllables, when occurring on W of iambic verse ( $\underline{\text { so }}$ well, too late) can weaken or lose stress in declamation. However, we adopt a formalized, consistent approach to stressing and take into consideration the part of speech of monosyllables, their placement on W or S syllabic positions, their syntactic function, and the distance from its syntactic partner (Kolmogorov, Prokhorov 2015 [1968]: 118-119; 2015 [1985]: 168). Following Zhirmunsky (1925; English translation: 1966), I divide monosyllables into three stressing categories: those that are always unstressed, both on S and W (articles, prepositions, conjunctions), always stressed (nouns, lexical verbs, adjectives, adverbs), and ambivalent: usually stressed on $\mathrm{S}$ and always unstressed on W (personal, demonstrative, possessive and relative pronouns; relative adverbs). Compare the pronoun thou in three lines from Shakespeare's sonnets: "Look in thy glass and tell the face thou viewest"; "If thou couldst answer "This fair child of mine"; "That thou amongst the waste of time must go" (Shakespeare, Son. 3.1, Son. 2.10, Son. 12.10). In the first line the personal pronoun thou fills a W syllabic position and is considered unstressed. In the second line the pronoun occupies an S and is immediately followed by its syntactic partner, the predicate; I mark it as unstressed, though it may be marked as stressed in another approach to stressing (Kazartsev 2015, 2017), and, of course, it may be stressed in declamation. In the third example, the subject thou also falls on an S position but it is separated from its predicate by a phrase: "among the waste of time". I considered thou stressed: it is located at a distance from its syntactic partner (Kolmogorov, Prokhorov 2015 [1968]: 118-119). Kazartsev follows Zhirmunsky's classification more consistently: all ambivalent monosyllables in his analysis are always stressed on S and unstressed on W. I find this scansion too heavy for English with its numerous monosyllables. 
During the early period of English iambic versification, poets and actors might have stressed ambivalent words more often than in the following periods (cf. Elizabethan vs. Jacobean plays). In Jacobean verse two syllables filling the same syllabic position are a frequent occurrence; they must have been pronounced faster than when each syllable filled one syllabic position, as it usually does in Elizabethan verse. The syllabic structure of verse lines hints at the change in the tempo of declamation. The place of the performance probably also played a role: in an inn yard under the open sky the actors had to shout out each word to be heard by the public, while in a roofed theater the tempo of declamation could have become faster. However, my approach to stressing texts of different periods is uniform. The placement of stresses in a text for its analysis is not equivalent to a declamation: there are more variants of declamation than of text analyses (Tarlinskaja 2002). The key to analysis is to explain the principle of stressing clearly and to apply it consistently.

For the stressing analysis of long texts, I use the simplified opposition "stress" vs. "non-stress". Degrees of stressing are taken into consideration in our analysis of separate lines and in special cases, e. g. "and WORSE still; ${ }^{2}$ he's DEAD then; but THUS much; he's WISE too". The emphasized words on W are often words of vague semantics. They probably required a weaker stress than their syntactic partner on S. Stressing on each W and S (all stresses on syllabic position 1 , syllabic position 2 , syllabic position 3 , etc.) is calculated as a percent from the total number of lines (Table 1). In early Renaissance the most numerous omitted stresses on S occurred on syllable 6, and so it did in early Shakespeare (see Kyd's The Spanish Tragedy and Shakespeare's Romeo and Juliet in Table 1). In post-1600 poetry the "dip" moved to syllable 8, and it did so in Shakespeare's verse. Here is an example of early Shakespeare's style: "That dogs bark at me as I halt by them" (Richard III, 1.1.23). And here is later Shakespeare: "Of all the under fiends. But if so be" (Coriolanus, 4.5.94).

The material in Tables 1-3 contain three plays by Shakespeare solo, four by Fletcher solo, three solo plays by Massinger, and five plays where Fletcher coauthored with other playwrights: Beaumont, Shakespeare, Massinger, and Rowley. ${ }^{3}$

\footnotetext{
2 Words in the capitals are strongly stressed and occupy a strong (S) syllabic position; nouns, verbs, adjectives and adverbs on W preceding the strong stress on $\mathrm{S}$ are termed proclitics ("too HOT"), nouns, verbs, adjectives and adverbs on $\mathrm{W}$ following the strong stress on $\mathrm{S}$ are termed enclitics ("He's DEAD then?" "A GOOD wench"). In counting stresses for the tables, "too" and "then" are marked as stressed, in declamation (as in "It is $\underline{\text { too }}$ HOT") their stress may be weakened, in analyzing separate lines and phrases these words are considered weakly stressed (Tarlinskaja 2002; 2014: Chapter 1).
}

3 In Tables 1 and 2 I have added the data on Kyd. 


\section{2}

The Second Test is the preferred placement of strong syntactic breaks. When determining syntactic links between adjacent words, I rely on grammatical categories, not on punctuation (cf. Oras 1960 and his followers, e. g., Jackson 2015). Table 2 demonstrates the percentage of strong syntactic breaks after syllables 2-11 calculated from the total number of lines. We differentiate three degrees of syntactic cohesion between adjacent words in verse: (1) a strong break [///], e. g., between sentences, clauses, or the author's and direct speech; (2) a medium break [//], as between subject and predicate (the building blocks of a sentence), a verb and an adverbial modifier of time and place, or between adjacent words that have no immediate syntactic link; and (3) a strong link [/], as between a modifier and a modified noun, or a verb and its direct object. The most frequent syntactic break in pre-1600 poetry fell after syllable 4 , and in post-1600 verse - after syllable 6, and so it did in Shakespeare's verse. In some Jacobean texts the break fell after syllable 7, as in earlier Fletcher. However, each poet added individual features to his verse style which help in attribution. Here is an example of marking degrees of cohesion between adjacent words: "The Jew // shall have / all justice. /// Soft, /// no haste" (Shakespeare, The Merchant of Venice, 4.1.320). Monosyllables on W, both unstressed and stressed, are drawn into the rhythmical unit with a stress on S: "These tidings // will well comfort / Cassius" (Shakespeare, Julius Caesar, 5.3.54). The speech units grouped around a stress on S are called "metrical words" (Gasparov 1974). Thus, "will well comfort" is a metrical word grouped around the syllable "com-" on S.

English phrases often begin with one or several unstressed grammatical monosyllables, therefore the syntactic line composition is related to its stressing. A break after syllable 4 predicts a frequent omitted stress on syllable 6 , and a break after syllable 6 often accompanies an omitted stress on syllable 8 . Here are examples from early and later Shakespeare; a syllable with an omitted stress is emphasized:

"Now is the winter // of our discontent

Made glorious summer // by this son of York..."

"And that so lamely // and unfashionable

That dogs bark at me /// as I halt by them."

(Shakespeare, Richard III, 1.1, 1-2, 22-23) 
"I would have voided thee; /// but in mere spite..."

"Stand I before thee now. /// Then if thou have

A heart of wreak in thee, /// thou wilt revenge..."

"As benefits to thee, /// for $\underline{I}$ will fight..."

(Shakespeare, Coriolanus, 4.5.85, 87-88, 93)

There are several more important features called "additional" (Table 3). Additional features greatly help attribution. Some of these features are particularly characteristic of Fletcher's style, for example the number of the so-called enclitic micro-phrases calculated per 1000 lines (see footnote 1). An "extrametrical" stress on W may occur to the left or to the right of the stress on $\mathrm{S}$. Phrases where a stress on $\mathrm{W}$ precedes a stress on $\mathrm{S}$ are called proclitics (as in "sweet BOY"), while phrases where a stress on W follows the $S$ are called enclitics ("Ye SPAKE well"). Enclitic phrases add to Fletcher's syncopated rhythm. Midline enclitics emphasize a "feminine" rhythm of Fletcher's verse, as in "Or BREAK down | hedges | for it. | - Dorothea |" (Fletcher, Monsieur Thomas, 1.3.56). The only playwright who used enclitic phrases as often as Fletcher was Middleton (Tarlinskaja 2014: Table 4B). When enclitic phrases terminate a verse line, they create a heavy feminine ending, as in "...my boy, my SWEET boy" (Fletcher, Bonduca, 4.2.78).

One more feature that is useful in attribution is the ratio of pleonastic verbs do per 1000 lines. Pleonastic do fills, when needed, a syllabic position, e. g.: "Not from the stars do I my judgement pluck" (Shakespeare, Son. 14.1). Shakespeare used pleonastic do lavishly throughout his writing career.

\section{Analyses}

3.1.

Stressing Within and at the End of the Line (Table 1). We compare four of Fletcher's solo plays and his collaborations with Shakespeare, Beaumont, Massinger, and Rowley. We also compare Fletcher with three Massinger's solo plays and his portion in The False One. Ants Oras compared Massinger's verse to prose (Oras 1960). We shall see what gave Oras such an impression. 
Kyd's The Spanish Tragedy (1586-87) and Shakespeare's Romeo and Juliet (1594-95) illustrate Elizabethan verse style, Henry V (1598-99) represents the short transitional period, and The Tempest (1610-11) shows the stressing tendency after 1600. The Spanish Tragedy and Romeo and Juliet, pre-1600 plays, have a stressing "dip" on syllable 6 . The year 1600 is conventionally considered a boundary between Elizabethan and Jacobean periods. John Fletcher (1579-1625) was younger than Shakespeare; all his plays were composed after 1600. Therefore, in all of Fletcher's plays analyzed the stressing "dip" always falls on syllable 8. Frances Beaumont (1584-1616), Philip Massinger (15831640 ) and William Rowley (1585?-1626), three of Fletcher's collaborators, were several years younger than Fletcher, their general styles were different, and yet the stressing distribution was similar, though for different reasons. Beaumont's later admirers praised him for his smooth verse and compared him to Shakespeare. Beaumont's portions of The Maid's Tragedy (1611) seem eleven-twelve years behind its period: its stressing on syllables 6 and 8 is equal (cf. Henry V). In Beaumont, this is a sign of smooth, archaic rhythm. Rowley's portion in the comedy The Maid in the Mill (1623), on the contrary, contains numerous gross syllabic irregularities and prose. One possible explanation of Rowley's more regular stressing in his iambic lines is that the author compensated the syllabic irregularities with a more regular stressing mode: a frequent stressing on syllable 4 , as it were, marks the end of the first hemistich, and an equal stressing on syllables 6 and 8 compensates the irregularities of his noniambic lines. Massinger's verse is also full of deviations, e. g., two syllables filling the same $\mathrm{W}$ position, underlined in the example below: "To the speech of my brother. - Have you moved him for us?" (Massinger, The City Madam, 1.2.105). Other features of Massinger's verse will be discussed below.

Fletcher's four solo plays and his portions in both The Maid's Tragedy and The Maid in the Mill show a firm "dip" on syllable 8, as was typical of the post1600 period.

Notice the stressing in Massinger's three solo plays and in his portion in The False One: the stressing "dip" on syllable 8 is very low $(64.9 \%$ of lines in The Maid of Honour, 65.6\% in The City Madam, and 64.2\% in his portion of The False One), while Massinger's stressing on syllables 2-4-6 varies. It is almost equal in two texts, in The Maid of Honour, 73.8-75.9-74.9\%, and in The False One, $72.4-76.3-75.4 \%$ of the lines (Table 1). A third play by Massinger has an equal number of breaks after syllables 5-6-7 (Table 2): The City Madam, 21.3-21.0-21.3\%. And the fourth play, A New Way to Pay Old Debts, has both an almost equal number of stresses on positions 2-4-6 (73.8-75.9-74.9\% of all lines) and an equal number of breaks after syllables 5-6-7, in the middle of the line (20.8-20.7-21.8\%). Equal stressing on positions $2-4-6$ and an equal 
percent of breaks after syllable 5-6-7 efface Massinger's hemistich segmentation and among other things (see below) make his verse prose-like.

Recall that there is a correlation between syntactic and accentual line composition. Particularly clear link between syntax and stressing is observed in the two early plays, Kyd's The Spanish Tragedy and Shakespeare's Romeo and Juliet: a strong syntactic break after syllable 4, the end of the first hemistich, calls for a new phrase and a frequent stressing "dip" on syllable 6 .

Fletcher's verse is more regular than Massinger's, and yet in Monsieur Thomas there is an equal amount of stresses on positions 4 and 6, and in the later Island Princess there is an increasing number of stresses on positions 2-4-6 and a Massinger-style "dip" on position 8 (67.7\% of the lines). In Fletcher's texts the stressing "dip" on position 8 is not as low as in Massinger's, and the "peak" on position 4 is almost always high (up to $90.8 \%$ in The Maid in the Mill): a sign of hemistich segmentation of Fletcher's lines. In The Island Princess the stressing "peak" occurs on position 6; it correlates with numerous breaks after position 6: $25.7 \%$ of all lines. The stressing "dip" on position 8 reminds us of Massinger: $67.7 \%$.

What is important is not just the percent of stresses on even syllables, but also their relative prominence between the two adjacent even syllables; e. g., in Shakespeare's portion of Henry VIII the percent of stresses on position 4 is relatively low (80.2\%), but it is surrounded by much lower indices: $68.3 \%$ on syllable 2 and $77.6 \%$ on syllable 6 . These numbers create a "peak" on syllable 4 .

One of the stressing features of Fletcher's lines are numerous enclitic phrases (Table 3). Compare the numbers of enclitics per 1000 lines by the two collaborators in The Maid's Tragedy: Fletcher 239.2, Beaumont 79.3: Fletcher used enclitics three times more often than Beaumont. Look at ShakespeareFletcher collaboration in Henry VIII: Shakespeare 68.6 enclitics per 1000 lines, Fletcher 226.5, again three times more often than his co-author. A similar correlation is observed in The Two Noble Kinsmen: Fletcher's portion has three times more enclitic phrases than Shakespeare's. Fletcher often filled the enclitic slot at the end of the line (syllable 11, heavy compound feminine endings) with words of vague semantics and decreased accentual prominence: too, still, now, then, yet and addresses: Sir, boy; e. g.: "And court her like a Mistris? Pray, your LEAVE yet" (Valentinian, 1.3.55). As mentioned above, Fletcher liked "feminine rhythm" within and at the end of his lines: "As your poor MIStresse | FAVour. | - I am MADE now" (Monsieur Thomas, 3.3.131). More about enclitics within and at the end of the line see below. 


\section{2 .}

Strong Syntactic Breaks (Table 2). Before 1600 Kyd, Shakespeare and other playwrights favoured the major syntactic break after syllable 4, e. g., Romeo and Juliet, 1594-95: "Supper is done, /4/ and we shall come too late"; "Some consequence, /4/ yet hanging in the stars" (Romeo and Juliet, 1.4.105, 107). In Henry $V$ (1598-99) the percentages of strong breaks after syllables 4 and 6 had become equal: the placement of strong breaks shows a transition from the earlier to the later style. The Tempest (1610-11), as all of Shakespeare's post-1600 plays, shows the most frequent break after syllable 6 . In The Tempest we found $30.0 \%$ of breaks after syllable 6 and only $17.7 \%$ after syllable 7 , e. g.: "Against my very heart... /6/ Poor souls, they perished"; "But are they, Ariel, safe? /6/ - Not a hair perished" (The Tempest, 1.2.9, 217). Most post-1600 authors preferred a break after syllable 6, however some playwrights placed the major break after syllable 7, e. g. Webster, Middleton, and early Fletcher (1610-14). This is what we see in Fletcher's solo plays Valentinian, Bonduca and Monsieur Thomas (all three plays are of the years 1610-14); e. g.: "Bears to oppose the Huntsman, /7/ were it nothing"; "Till thou wert such as they are? /7/ - Chimney pieces" (Valentinian, 1.2.20, 2.2.14). The break after syllable 7 often correlates with feminine line endings: there is more space for a second hemistich if the line has a feminine ending. In Valentinian this tendency is particularly obvious: only $18.4 \%$ of breaks fall after syllable $6,26.8 \%$ after syllable 7 , and almost 74\% feminine line endings. As mentioned above, Fletcher preferred a feminine rhythm both within the line and at its end, e. g. "Despair not, /3/ 'tis not manly /7/: ONE hours /9/ goodness /11/" (Fletcher, Monsieur Thomas, 3.1.375).

In Fletcher's collaborations with Shakespeare and Beaumont (1611-13), Fletcher placed the major break after syllable 7, while his co-authors have most breaks after syllable 6. In Fletcher's later texts, The Island Princess (1619-21) and his portion in The False One (1620), the major break occurs after syllable 6: this signifies a change of the tendency compared to his earlier plays, Valentinian, Monsieur Thomas and Bonduca (1610-14). While in Valentinian we found $28.8 \%$ of breaks after syllable 7 and only $18.4 \%$ after syllable 6 , in The Island Princess we find $25.7 \%$ of breaks after syllable 6 and only $17.8 \%$ after syllable 7 : the style has radically changed. The same correlation occurs in Fletcher's portion of The False One: $26.6 \%$ of breaks fall after syllable 6 and only 16.2\% after syllable 7. Massinger, Fletcher's coauthor in The False One (1620) places an equal number of breaks after syllables 6 and 7 (21.8 and 22.2\%).

In The Maid's Tragedy (1610-11) by Fletcher and Beaumont, Beaumont has two "peaks" of breaks, the major break after syllable 6 (28.5\%) and another one 
after syllable 4 (23.4\%): an earlier style. Fletcher's rhythm began to change in later plays. As shown above, in The Island Princess (1619-21) the major break moved one syllable back, to fall after syllable 6 as in "What would you have me do? /6/ Reach me a chair" (Fletcher, The Island Princess 1.3.1). This is a sign of changing tastes: at the end of the Jacobean and the beginning of the Carolinian epochs the authors began to smooth out the rhythm, and the major break moved from after syllable 7 to after 6 . Sometimes the number of breaks after syllables 6 and 7 becomes equal, as in Massinger's portion of The False One, or even equal after syllables 5-6-7, as in Massinger's solo plays A New Way to Pay Old Debts (1625) and The City Madam (1632). This feature effaces the hemistich segmentation of Massinger's lines. The previously discussed trait of Massinger's verse was an equal number of stresses on positions 2-4-6, as in The Maid of Honour and The False One. Equal stresses and equal breaks in midline efface the hemistich segmentation of Massinger's iamb. These traits, among others, probably made Massinger's verse sound like prose to Ants Oras.

Later, during the post-Restoration period, and much later, during Dryden's lifetime and early Classicism, the major break began to fall after syllable 4, e. g.: "To Wives and Slaves; /4/ And, wide as his Command" (Dryden, Absalom and Achitophel, 9); "Beware of all, /4/ but most beware of Man!" (Pope, The Rape of the Lock, 1.114): a masculine rhythm prevails, and syllable count is precise: no cases of two syllables filling the same metrical position.

In the later collaborated plays there is a mixture of tendencies that indicate a transitional period. In The False One (1620), as shown above, Massinger's portion has an equal percent of breaks after syllables 6 and 7 (21.8\% and 22.2\%), while in Fletcher's portion the major break falls only after syllable 6 (26.6\%). In The Maid in the Mill (1623) Fletcher again places the major break after syllable 6 (29.9\%) and two minor ones after syllables 4 and 8 (26.1 and $25.1 \%$ of the lines). This correlation signifies a new trend: short syntactic units spread along the line. Rowley's iamb, on the contrary, has just one major break, after syllable 6 . Thus, Fletcher's style had changed from Valentinian and two other earlier plays, with a break after syllable 7, to The Island Princess and The False One with major breaks after syllable 6 to The Maid in the Mill with prominent breaks after syllables 6, 4 and 8. Massinger's A New Way to Pay Old Debts (1625) has an equal number of breaks after syllables 5, 6 and 7: 20.8-20.7-21.8\%. This line configuration effaced Massinger's hemistich line structure. Recall that the syllabic structure of Massinger's plays also makes his verse sound prose-like: he regularly fits two syllables into the same metrical slot; e. g.: "I pawn'd you my land for the TENTH part of the value" (Massinger, The City Madam, 1.2.69, 1.3.6). The line contains two cases of two syllables occupying the same metrical slot (syllabic positions 3 and 5); the line, in addition, contains an enclitic phrase within the line. 
Here is another important feature that makes Massinger's verse sound prose-like: he often divided the line into two syntactic halves, and the second half-line ran into the next line. In the example below, the second half of line 61 ("enterTAIN 'em $\rightarrow$ ") 4 is a compound light feminine ending, and it runs-over onto line 62. The boundary between lines 61 and 62 is effaced:

"I am visited by any, /7/ enterTAIN 'em $\rightarrow$

As theretofore; /4/ but say, in my excuse"

(Massinger, A New Way to Pay Old Debts, 1.2.61-62)

This kind of syllabic and syntactic line structure does not occur in the texts by other playwrights.

In his three earlier solo plays Fletcher prefers a break after syllable 7, and so he does in his early collaborations with Shakespeare in Henry VIII and The Two Noble Kinsmen, and in The Maid's Tragedy with Beaumont. In Shakespeare's portions the major break falls after syllable 6 , and in Beaumont's portion there are two peaks, after syllables 6 (28.5\%) and 4 (23.4\%). Beaumont's verse structure vacillates between $6+4$ and $4+6$ syllables. In the later collaborations with other playwrights the picture begins to change: Massinger in his portion of The False One (1620) has an almost equal number of breaks after syllables 6 and 7 (21.8 and $22.2 \%$ of the lines), while Fletcher creates just one major break, after syllable 6 (26.6\%). In The Maid in the Mill, Rowley also has just one major break, again after syllable 6 , while Fletcher moves his breaks both ways: the main break still falls after syllable 6 (29.9\% of all lines) and two minor ones occur after syllables 4 and 8 (26.6 and $25.1 \%$ of the lines). This is the result of changed line syntax: the utterances and phrases have become shorter, e. g.: "To me, Sir? [4] From whom? /6/ - A friend, /8/, I dare VOW, sir." (Fletcher, The Maid in the Mill, 2.2.336). " "I dare" fill the same metrical slot, position 9. The line has four phrases; there is a missing syllable (syllable four, in square brackets), and a compound heavy feminine line ending.

The first three collaborations, one by Fletcher-Beaumont and two by Fletcher-Shakespeare, were created during the years 1611-13, while the two other collaborations, The False One with Massinger and The Maid in the Mill with Rowley, were composed ten years later, 1619-23 and 1623. These were the

4 The arrow denotes an enjambment.

5 The number in square brackets (e.g. [4]) shows an omitted syllable in the iambic line, in this case an omitted syllable four, while the number in slanted brackets (e.g., /6/) shows - as everywhere else in this article - a word boundary, in this case, after syllabic position six. 
years when Fletcher's verse style began to change; in The Island Princess most breaks fall after syllable 6, not 7. The percent of breaks in The Island Princess is $25.7 \%$ after syllable 6 and only $17.8 \%$ after syllable 7 . In the earlier Valentinian the numbers are the reverse: $18.2 \%$ after syllable 6 and $26.8 \%$ after 7 .

Beaumont in his portions of The Maid's Tragedy, as mentioned above, placed syntactic breaks after syllables 6 (28.5\%, the main break) and 4 (23.4\%). This is a feature of Beaumont's old-fashioned style; the other features were a careful syllable count and an old-fashioned stressing pattern, as though twelve years earlier (cf. Henry V). After Beaumont died, the general style kept evolving, with a break falling first after syllable 6 (Shakespeare), then after syllable 7 (early Fletcher), then back again, after syllable 6 (The Island Princess). Fletcher's portion of The Maid in the Mill with its three peaks of breaks, after syllables 6, 4 and 8 illustrates the changing tendency in Fletcher: from a break after syllable 7 - to a break after syllables 6 - to breaks after syllables 6, 4 and 8 in The Maid in the Mill (29.9, 26.1 and 25.1\% of lines). Syllabic and syntactic structure of the lines is looser here, and it affects the placement of breaks. An example: "Give it me // again. /// Come, come, /// fly, fly. /// I am all fire" (Fletcher, The Maid in the Mill, 1.2.99). "Give it" is squeezed into the same W slot. "I am all fire" may be interpreted as three syllables placed into the same W position ("I am all"). Another variant of interpretation: the line has six strong syllabic positions (a hexameter line). Then it must be discarded from our analysis.

\section{3.}

Line Endings (Table 3). We analyzed the syllabic and accentual composition of line endings and their syntactic features. From the point of view of their syllabic structure we differentiate masculine, feminine, and dactylic endings. Feminine and dactylic endings can be simple (as in MUR-der; MUR-de-rer) or compound (KILL-him, CAME-to-him). From the point of view of stressing, masculine endings can be stressed or unstressed. Unstressed syllable 10 in masculine endings can be the end of a polysyllabic word ("O villains, Chiron and Demetrius!" - Titus Andronicus, 5.3.8) or an unstressed grammatical monosyllable; the latter cause run-on lines:

“...Perchance he spoke not, $\underline{\text { but }} \rightarrow$

Like a full-acorned boar, a German one..."

(Shakespeare, Cymbeline, 4.5.15)

Run-on lines are a syntactic feature of mostly masculine line endings. Feminine endings, as we shall see, avoid enjambments. 


\subsection{1.}

Compound Feminine and Dactylic Endings. Compound feminine and dactylic endings can be light (unstressed on syllable 11 or 12) or heavy, stressed on syllables 11 or 12, as in "...Worse, worse, and WORSE still”" (Fletcher, Monsieur Thomas, 1.3.111). Here are lines with heavy dactylic endings: "And pray ye speak truly too. - I never LYDE, Lady" ("ye speak" fill the same syllabic position, three). "A thousand kisses. - Take ten thousand BACK again" (The Maid in the Mill, 1.3.59, 124). Both heavy feminine and heavy dactylic endings prefer words with a reduced phrasal accentuation: monosyllables too, so, still and direct addresses (Sir, boy) on position 11 in heavy feminine endings, while heavy dactylic endings favor disyllabic adverbs of vague semantics and reduced stress: enough, again ("not GOOD enough," "got UP again"), reflexive pronouns ("go CLEAN yourself") and phrase-final direct addresses ("Don't CRY, lady"). ${ }^{6}$ Yet even lighter dactylic endings avoid run-on lines: the end of the line must be marked either by its syllabic structure, or its accentual and syntactic composition. In Shakespeare's The Tempest we found $42 \%$ lines with enjambments, only $35.6 \%$ feminine endings, and only a couple of heavy feminine endings. Compare these numbers with Fletcher's Valentinian, the same period: 73.5\% feminine endings (more than twice as many as in The Tempest), 7.3\% heavy feminine endings, and only $13.5 \%$ enjambments, one-third of those in The Tempest. In Fletcher's Bonduca we found only $17.1 \%$ enjambments, but almost $67 \%$ feminine endings (almost twice as many as in The Tempest) and 9\% compound heavy feminine endings (but almost none in The Tempest). Thus, all Fletcher's solo plays have numerous feminine endings, including compound heavy feminine endings, and very few run-on lines. The number of enjambments decreased in later collaborations: Fletcher in The False One: 8.1\% run-on lines (and 80.9\% feminine endings, $\mathbf{1 0 . 7 \%}$ heavy feminine endings), in The Maid in the Mill there are only $6.2 \%$ enjambments, and $77.9 \%$ feminine endings, 35\% compound feminine endings, and $\mathbf{1 9 . 6 \%}$ compound heavy feminine endings. Feminine and dactylic endings preclude enjambments. Only Massinger frequently used compound light feminine endings together with enjambments (see below).

Let us look at the line endings in other collaborated plays. Shakespeare's scenes in Henry VIII contain 33.5\% feminine endings, and Fletcher's scenes almost twice as many: $63.4 \%$. The number of run-on lines is the reverse: $45.7 \%$ in Shakespeare's scenes, and only $28.3 \%$ in Fletcher's. This is a high number for

\footnotetext{
6 Disyllabic enclitics in post-positional direct address occur in Shakespeare's texts in midline, not necessarily at the end of the line: "We are not SAFE, Clarence, we are not safe" from Richard III, or "FareWELL, brother! -We split, we split, we split" from The Tempest.
} 
Fletcher: Fletcher was undoubtedly influenced by his co-author. In Fletcher's Monsieur Thomas (1613-19) we find 80.3\% feminine endings, 33.9\% compound feminine endings, $17.7 \%$ of heavy feminine endings, and only $16.4 \%$ run-on lines. Cf. with Middleton's A Game at Chess (1624): there are fewer feminine endings, only $59.4 \%$, and consequently more run-on lines: $27.8 \%$. Look at The Maid in the Mill. Here too Fletcher has numerous feminine endings (almost 78\%), 35\% compound feminine endings, many heavy feminine endings (19.6\%) and, consequently, very few run-on lines: only $6.2 \%$. In Rowley's portion the situation is reversed: only $45.8 \%$ of feminine endings, only $7.5 \%$ heavy feminine endings (almost one-third of Fletcher's 19.6\%) and 22.9\% run-on lines (three times more than in Fletcher's portion). A similar tendency is observed in The False One by Fletcher and Massinger. We find only 8.1\% run-on lines in Fletcher's scenes, and four times as many in Massinger's: $36.9 \%$, while the percent of feminine endings is the reverse: $80.9 \%$ feminine endings in Fletcher's scenes and only $43.6 \%$ in Massinger's. Thus, to reiterate, feminine endings, particularly compound heavy feminine endings, preclude enjambments. Compound heavy feminine endings preclude enjambment even in Massinger's verse: the heavy feminine ending places a definite syntactic boundary between adjacent lines:

"The fattest stag I ever cooked." - "A STAG, man?"

"A stag, Sir, part of it prepared for dinner -"

(Massinger, A New Way to Pay Old Debts, 1.3.19-20)

Line endings are a remarkable feature of Massinger's verse. The three solo plays have a close number of feminine endings, particularly A New Way to Pay Old Debts and The City Madam: 52.6 and 57.1\% of lines; and compound heavy endings are identical: The Maid of Honour 5.0\% of all lines, A New Way to Pay Old Debts 5.5\%, and The City Madam 5.4\%.

\subsection{2.}

Compound Light Feminine Endings in adjacent lines efface the boundary between the lines, if the lines are linked syntactically. Such lines are typical of Massinger, but not of Fletcher. Here are some examples from Massinger's texts:

"Which we that are her servants /7/ ought to serve it $\rightarrow$

And not dispute. /4/ Howe'er you are nobly welcome..."

(Massinger, A New Way to Pay Old Debts, 1.3.5-6) 
"Cannot speak more effectually. /8/ Shall I be $\rightarrow$

Talk'd out of my money?" /5/ No, sir, but entreated..."

(Massinger, The City Madam, 1.3.97-98)

Here "of my" occupy the same syllabic position, three; "effectually" is considered tetrasyllabic. Thus, if the ending of the first line is compound light feminine, and if it runs into the second line, the line segmentation is effaced. This is the most important feature of Massinger's verse that might have reminded Oras of prose. Such lines do not occur in Shakespeare.

While feminine endings, and particularly compound heavy feminine endings, avoid enjambments, masculine endings are frequently paired with run-on lines, especially if position 10 is filled with an unstressed grammatical monosyllable, very frequent in late Shakespeare.

Syllabic and syntactic types of line endings are two of the numerous factors that oppose Fletcher and his co-authors (Table 3). In spite of the genre difference and the persona of Fletcher's co-author, we see that Fletcher strongly preferred feminine endings, especially heavy feminine endings, and avoided run-on lines both in solo plays and collaborations. In The False One with Massinger the correlation between the feminine line endings is as follows: Fletcher $80.9 \%$, Massinger $43.6 \%$, while run-on lines show a reverse tendency: Fletcher $8.1 \%$ and Massinger $36.9 \%$ of all lines. The same tendency is revealed in other collaborations, The Maid's Tragedy with Beaumont, and particularly The Maid in the Mill with Rowley: feminine endings in Fletcher's portion reach $77.9 \%$ of the lines, in Rowley's $45.8 \%$, while run-on lines are the reverse: Fletcher $6.2 \%$ and Rowley almost 23\%. Let us go back to The Two Noble Kinsmen by Shakespeare and Fletcher: compound feminine endings reach $22.9 \%$ in Fletcher's portion, and only 6.4\% in Shakespeare's. Heavy feminine endings reach $8.7 \%$ of lines in Fletcher's portion, and only $1 \%$ in Shakespeare's. The run-on lines reach $52.8 \%$ in Shakespeare's portion and only $21.5 \%$ in Fletcher's (and this is still too many for Fletcher: here too he was influenced by his co-author Shakespeare).

\subsection{3.}

\section{The syllabic and syntactic types of line endings (a summary).}

Feminine endings. Henry VIII: Shakespeare 33.5\%, Fletcher almost twice as many: $63.4 \%$. The Two Noble Kinsmen: Shakespeare 32.6\%, Fletcher 58.4\%: Fletcher almost doubled the Shakespearean number. The Maid's Tragedy: Fletcher 54.6\%, Beaumont only 15.0\%, almost a quarter of Fletcher's number, and all Beaumont's feminine endings are simple. The False One: Fletcher 80.9\% 
of feminine endings and Massinger $43.6 \%$, almost one half of Fletcher's number. The Maid in the Mill: Fletcher 77.9\% lines with feminine endings, Rowley $45.8 \%$. Thus, Fletcher used feminine endings approximately 2-4 times more often than his co-authors. How do these data correlate with run-on lines?

Run-on lines. The picture is the reverse. Look at Fletcher and Shakespeare in Henry VIII: Fletcher $28.3 \%$ and Shakespeare $45.7 \%$ of the lines: Fletcher has almost half the number of run-on lines compared to his feminine endings (63.4\%). Shakespeare obviously had influenced Fletcher: $28.3 \%$ is too many enjambments for Fletcher. Look at The Two Noble Kinsmen: Shakespeare has 2.5 times more run-on lines compared to Fletcher: Shakespeare $52.8 \%$ and Fletcher 21.5\%. In The False One Massinger and Fletcher are even farther apart: only $8.1 \%$ run-on lines in Fletcher's scenes (not unlike his solo plays) and four times more, 36.9\% run-on lines in Massinger's. In The Maid in the Mill Fletcher has only 6.2\% enjambments, and Rowley $-22.9 \%$, almost four times more than Fletcher.

Though Fletcher uses more feminine endings and fewer run-on lines than his collaborators, co-authors influenced each other: cf. Fletcher solo, Valentinian 13.5\% run-on lines, and Fletcher in Henry VIII (the same period as Valentinian) 28.3\%: an influence of Shakespeare, who has $45.7 \%$ run-on lines. In Massinger's three solo plays, the number of compound endings increases with time: $15.0,18.1$ and $20.6 \%$ while the ratio of heavy endings is very close: 5.0, 5.5 and 5.4\%: about a third or one-fourth of the compound endings.

Fletcher always used few enjambments both in his solo plays and in collaborations; The Island Princess (1619-21 or 1623) particularly stands out for its few run-on lines: only $11.5 \%$ lines are run-on. The highest number of enjambments in Fletcher's solo plays is in Bonduca: 17.1\%, still much below Shakespeare's numbers: in The Tempest, the last solo play by Shakespeare, there are $42.0 \%$ run-on lines, and a similar number in Henry VIII: 45.7\%. Both plays were composed at about the same time. In Shakespeare's portion of Two Noble Kinsmen there are particularly many run-on lines: 52.8\%, and in Fletcher's portion only $21.5 \%$, two and a half times less frequent than in Shakespeare's scenes, yet much more often than in his solo plays.

Shakespeare often composed run-on-lines placing grammatical words on position 10 in masculine endings:

"Had I been any god of power, I would $\rightarrow$

Have sunk the sea within the earth..."

(Shakespeare, The Tempest, 1.2.10) 
Massinger, as pointed out above, unlike Shakespeare and Fletcher, often used compound light feminine endings that ran over onto the next line. Here are three more examples:

"With hopes above their birth and scale /8/ Their dreams are $\rightarrow$

Of being made countesses /6/ and they take state..."

"That such as soar above their pitch /8/ and will not $\rightarrow$

Be warn'd by my example, should like me..."

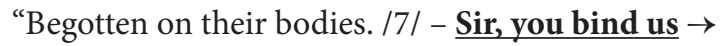

To very strict conditions. - You, my lord...”

(Massinger, The City Madam, 1.1.17-18, 1.2.118-119, 2.2.5-6)

This feature more than anything else makes Massinger's verse sound like prose.

Recall that Fletcher favored syntactically complete lines with numerous feminine endings, including heavy feminine endings. Below are three lines illustrating typical Fletcher. As mentioned above, Fletcher was fond not just of feminine endings, but of feminine rhythm within his lines. Two of the three lines below have a heavy feminine ending, and in the second line there is, in addition, a heavy feminine ending of the first hemistich.

"And court her // like a Mistris? /// Pray /// your LEAVE yet"

(Fletcher, Valentinian, 1.3.54)

"As many // foolish / MEN $\underline{\text { doe }}$, // I should RUN mad"

"Despise not, /// 'tis not manly: /// ONE hour / goodness..."

(Fletcher, Monsieur Thomas, 1.1.153, 3.1.375)

A striking difference opposes Fletcher to his co-authors, Shakespeare, Beaumont, Massinger and Rowley. Look at the difference in a later collaborated play, The False One. The difference is in the number of run-on lines: $36.9 \%$ in Massinger's portion and only $8.1 \%$ in Fletcher's.

Massinger, like Rowley but unlike Fletcher, regularly inserted two syllables into the same metrical slot; this makes some of his lines difficult to interpret. Recall that we found three other important features of Massinger's versification style that make his verse prose-like: a similar percent of stresses on positions 2-4-6 (73.8-75.9-74.9\% in The Maid of Honour, 72.4-76.3-75.4\% in The False One), a similar percent of syntactic breaks after adjacent syllables 5-6-7, that 
is, in the middle of the line: A New Way to Pay the Old Debts 20.8-20.7-21.8\%, The City Madam 21.3-21.0-21.3\%. Thus, Massinger's hemistich segmentation is effaced. And the third important feature in Massinger's texts that makes it prose-like is a break in mid-line and a compound light feminine ending that runs over into the next line: the segmentation of Massinger's texts into lines is effaced.

The number of run-on lines contrasts Fletcher to his collaborators, particularly in The False One with Massinger and The Maid in the Mill with Rowley: only 8.1 and 6.2\% run-on lines in Fletcher's portions, and 36.9\% in Massinger's portion and $22.9 \%$ in Rowley's.

The total percent of feminine endings in Fletcher's solo plays is the highest in the material analyzed: $66.9-80.3 \%$ of all lines (Bonduca - Monsieur Thomas). The next in line, Thomas Middleton and John Ford (Tarlinskaja 2014: Appendix B, Table 4) never rise above $60 \%$ of feminine endings. The total number of feminine endings does not always correlate with the number of heavy feminine endings. In Massinger's three solo plays the percent of feminine endings increases with time $(47.4,52.6$ and $57.1 \%)$ and so does the amount of compound feminine endings (15.0, 18.1 and $20.6 \%$ of all lines), while the amount of heavy feminine endings remains the same: 5.0, 5.5 and $5.4 \%$.

Compared to the total number of feminine endings, the percentage of heavy endings in Fletcher's plays is relatively low: Monsieur Thomas $80.3 \%$ of feminine endings but only $17.7 \%$ lines with heavy endings; The Island Princess has $76.8 \%$ feminine endings and only $11.8 \%$ heavy feminine endings. However, if we count only compound feminine endings, the numbers rise in favor of heavy endings: Monsieur Thomas: $33.9 \%$ compound feminine endings and $17.7 \%$ heavy endings, half of the total; The Island Princess: $32.1 \%$ compound feminine endings and $11.8 \%$ compound heavy: one third of compound feminine endings are heavy. The same correlation is seen in Valentinian: 20.3\% lines with compound feminine endings and $7.3 \%$ of heavy feminine endings: one third of the compound endings are heavy. In The Maid in the Mill Fletcher has 35\% of compound feminine endings, and $19.6 \%$ lines with heavy feminine endings: more than half of the total. This might be another way of looking at the material.

\section{4.}

Enclitic Phrases. We have been mentioning enclitic micro-phrases many times above. Enclitics are often placed at the end of a longer phrase, creating a syncopated rhythm. Compound heavy feminine line endings are at the same time enclitics. Here is a line with a heavy ending (i. e. enclitic) of the first hemistich and a heavy ending of the line; it may be considered a feminine or a 
dactylic ending: the name Alice is ambivalent, either monosyllabic or disyllabic (cf. Arden of Faversham): "He'll catch no FISH else. Farewell Doll - FareWELL Alice" (Monsieur Thomas, 1.3.138). There are more enclitics in Fletcher's solo plays than in his collaborations.

The lowest number of enclitics occurs in Shakespeare's portions of Henry VIII and The Two Noble Kinsmen, and in Beaumont's portion of The Maid's Tragedy (68.6, 89.2 and 79.3 per 1000 lines). The highest number of enclitics is in Fletcher's Monsieur Thomas: 410.5 per 1000 lines. Co-authors often influence each other's styles, but there are always more enclitic phrases in Fletcher's portions than in those of his collaborators. This is how Shakespeare's portions in Henry VIII and The Two Noble Kinsmen were identified: Henry VIII, Shakespeare 68.6 and Fletcher 226.5 enclitics per 1000 lines, three times more than in Shakespeare's portion; The Two Noble Kinsmen: Shakespeare 89.2 and Fletcher 290.1 enclitics per 1000 lines, also three times more often than in Shakespeare's portion. Here are some examples of enclitic phrases in "The Two Noble Kinsmen":

Like TALL ships under sail; then start amongst 'em...

And like an EAST wind leave 'em all behind us...

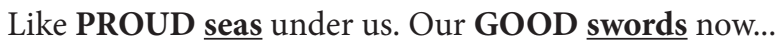

But dead-cold winter must inhabit HERE $\underline{\text { still }}$

Consider The Maid's Tragedy: Beaumont 79.8 and Fletcher - 239.2 per 1000 lines, again three times more often than in his co-author. Beaumont's style was not unlike Shakespeare's. Look at Rowley and Fletcher's portions in The Maid in the Mill: Rowley 74.8 and Fletcher 307.7 enclitics per 1000 lines: Fletcher's enclitics are four times more frequent than Rowley's. The most frequent correlation between enclitic phrases as used by Fletcher and his collaborators is 3:1. However, the correlation is 2:1 in The False One by Massinger and Fletcher: 118.3 and 234.9 per 1000 lines: Fletcher's enclitics occurred "only" twice as often as Massinger's (not three-four times more often): Massinger used numerous run-on lines, and these preclude enclitics. Only Middleton can compare with Fletcher in the ratio of enclitics: The Witch 274.8, A Game at Chess 270.5 per 1000 lines. Massinger in his solo plays uses relatively few enclitic phrases, and the number of enclitics increases from the earlier to the later play: 141.6 in The Maid of Honour, 174.1 in A New Way to Pay Old Debts, and 225.1 in The City Madam.

Among Fletcher's solo plays Bonduca and The Island Princess stand out. They portray the occupation of one country by another; it parallels the occupation by contemporary England of the Virginia Islands. Structurally, Bonduca 
is marked by syllabic regularity, many rhythmical italics (199.8 per 1000 lines, cf. The Tempest and the Shakespeare's portion in Henry VIII), many alliterations (223.7 per 1000 lines; cf. Valentinian 142.4 and Monsieur Thomas 107.4 per 1000 lines), and a relatively high number of the disyllabic suffixes -ion. All these features must have made Oliphant conclude that Bonduca was earlier than Valentinian, itself considered an early play (compare: "I would assume that this play [Bonduca] [...] was in its first form of very early date" - Oliphant 1927: 131). Martin Wiggins dates Bonduca 1613 when it was first staged. If not the date, there must be some other explanation why Bonduca is so different from Fletcher's other solo plays.

Notice the enclitic phrase in the line from Valentinian, 1.1.54 "That, that had made a SAINT start, well considered"; this enclitic phrase is syntactically a subject and a predicate. Such syntactic patterns are rare and were used for emphasis ("The AXE falls", "The ROCK bleeds"). Attributive and adverbial patterns and direct addresses are much more common as enclitics. End of the line enclitics that are at the same time heavy feminine endings were counted twice, as an enclitic and a heavy feminine ending.

The difference in the number of enclitic phrases is also found in the Fletcher-Rowley's The Maid of the Mill: Rowley 74.8, Fletcher 307.7 enclitics per 1000 lines, four times more often than Rowley. The contrast between the co-authors in The False One is not as striking: Fletcher 234.9 and Massinger 118.3. Massinger was fond of enclitic phrases, but never reached Fletcher's frequency: Massinger has many run-on lines, and these, as we know, preclude heavy feminine endings. Feminine endings and run-on lines are usually in inverse proportion: the more compound heavy feminine endings in the text, the fewer run-on lines. Enclitic phrases, both in mid-line and at the end of the line, including heavy feminine line endings, tend to incorporate monosyllables with vague semantics and a reduced phrasal accentuation: else, too, then ("in LOVE too", "He's DEAD then?"). Heavy dactylic endings, as mentioned above, often contain disyllables with a vague semantics and reduced phrasal accentuation: postpositional addresses ("Lady, Caesar"); e. g. "Go OFF, Caesar" from Massinger's portion of The False One; reflexive pronouns yourselves, myself ("prePARE yourself") and adverbs again and enough ('aLIVE again, he's WELL enough"). These were particularly typical of Middleton. E. g.:

"Kept you this place still? Did you not reMOVE, lady?"

"Dare not once think awry, but must conFESS ourselves"

"I speak not to thee - and you did prePARE yourself ..."

(Middleton, A Game at Chess, 4.1.99, 9, 5.2.85) 
Fletcher preferred heavy feminine endings, however, a few dactylic endings were found in Fletcher's portion of The Maid of the Mill: "Though some deserv'd it Sure we were all to BLAME, Lady" (1.2.76); "we were" serves as a single syllable. Also: "I never LYDE, Lady" (1.3.79); "A thousand kisses - Take ten thousand BACK again" (1.3.124). The Maid of the Mill is a comedy with numerous deviations in its syllabic and accentual composition, particularly in Rowley's portion. Rowley often created lines with an omitted syllable on a syllabic position (especially often on syllabic positions 1 and 7), or with two syllables occupying the same syllabic position. Rowley's style probably influenced Fletcher's. Here are two lines from Rowley's portion with omitted syllables on positions 7 and 4 (omitted syllables are marked by a number in square brackets):

"No Gill, I have been mad [7] these five hours"

"And hear me? [4] the King's neer by in progresse"

(Rowley, The Maid in the Mill, 3.1.45, 49)

And here is an example of Rowley's line with two monosyllables on position 5 (underlined) and an omitted syllable seven (in square brackets):

"The dogs shall eat him in Lent, [7] there's Cats meat"

(Rowley, The Maid in the Mill, 3.1.57)

It is remarkable how much alike are Beaumont and Shakespeare in their collaborations with Fletcher: Shakespeare, Henry VIII 68.6 enclitics per 1000, The Two Noble Kinsmen 89.2, Beaumont in The Maid's Tragedy 79.3, while Fletcher keeps to his high numbers: 226.5, 290.1 and 239.2 per 1000 lines. The enclitics test is particularly useful for attribution. A high number of enclitics is Fletcher's hallmark.

Disyllabic enclitics appear in Shakespeare's early plays in the middle of the line in the function of direct addresses:

"We are not SAFE, Clarence, we are not safe"

"My Lady Gray his WIFE, Clarence, 'tis she"

(Shakespeare, Richard III, 1.1.70, 65)

Disyllabic enclitics appear in the middle of the line if they follow a strong stress:

"...They and the seconds of it

Are BASE people. Believe them not, they lied"

(Fletcher, The Maid's Tragedy, 4.1.43-44) 


\section{5.}

More additional features. We cannot discuss every "additional" feature, but here are two more. The first one is the frequency of pleonastic verb do ("That every word doth almost tell my name", Son. 76.7). This feature is important because it opposes Shakespeare to Fletcher, and Beaumont to Fletcher in solo plays and collaborations. There are numerous pleonastic verbs do in Shakespeare and Beaumont's texts (Table 3). For example, in The Maid's Tragedy there are 29.4 per 1000 lines of the verb do in Beaumont's scenes and only 5.4 in Fletcher's. In Shakespeare's portion of Henry VIII there are 42.8 pleonastic do per 1000 lines, and only 3.7 in Fletcher's. In The Two Noble Kinsmen Fletcher has only 0.8 pleonastic do per 1000 lines, and Shakespeare has 31.4. Shakespeare used pleonastic do all his creative life, while Fletcher didn't, even in the earlier plays. Even Massinger and Rowley are opposed to Fletcher in the ratio of pleonastic do; e. g. in The False One Fletcher uses only 3.9 pleonastic do per 1000 lines, and Massinger 19.2.

One more additional feature is the use of disyllabic variant of the suffix -ion. Examples: "There lies the main con-si-de-ra-ti-on"; "My noble Friend from whose in-struc-ti-ons"; "Not thinke I speak it with am-bi-ti-ons" (Fletcher, Valentinian, 1.2.75, 1.3.32, 34). Fletcher uses 9.5 disyllabic -ion per 1000 lines in Bonduca, 5.9 in Valentinian, 5.3 in The Maid's Tragedy, 5.4 in The Two Noble Kinsmen and 6.2 in The False One. Massinger uses the disyllabic suffix -ion almost three times more often in the early Maid of Honour than in the later The City Madam: 14.7 and 4.6 per 1000 lines. Shakespeare used the disyllabic variant of the suffix 7.7 times per 1000 lines in Romeo and Juliet, and only 1.5 times in The Tempest. The disyllabic variant of the suffix -ion was beginning to feel obsolete. Earlier playwrights, such as Marlowe, used the disyllabic variant of the suffix -ion much more frequently, to prolong the end of the line; later playwrights used disyllabic -ion to mark the genre of tragedy, e. g., Shirley (cf. Tarlinskaja 2014: Appendix 4B).

\section{Conclusion}

In many ways Fletcher's versification stayed within the parameters of the Jacobean period, e. g., the most frequent syntactic break after syllable 7, a stressing "dip" on syllable 8, a stressing "peak" on syllable 4. Feminine endings, particularly compound heavy feminine endings are very frequent, and in inverse proportion to run-on-lines: the more compound feminine endings in the text, the fewer run-on lines. Fletcher's style has idiosyncratic features, by 
which his texts are easily recognized. The most specific features of Fletcher's versification are numerous feminine line endings, many enclitic phrases including heavy feminine line endings, and few run-on lines.

Fletcher's verse style is not unlike Thomas Middleton's. Middleton, however, used heavy dactylic endings and run-on lines much bolder than Fletcher. Both Fletcher and Middleton composed heavy feminine endings using words of vague semantics and a lighter phrasal stress: too, so, then, still (as in "Be SURE then", "And women you shall THANK too," "Worse, worse, and WORSE still") and phrase-final direct addresses, such as child, friend, Sir. Heavy dactylic endings prefer end-of-the phrase direct addresses ("I never LYDE, Lady"), reflexive pronouns (herself, yourself) and disyllabic adverbs of vague semantics ("BACK again", "SOON enough"). Numerous enclitic phrases, many feminine endings including heavy feminine endings, and few enjambments helped to identify Fletcher in collaborative plays.

Massinger's verse is prose-like, as Ants Oras noticed: there are numerous cases of two syllables fitted into the same metrical slot; there is no visible hemistich segmentation: we found an equal number of breaks after syllables 5 , 6,7 and an equal number of stresses on syllabic positions 2-4-6. But the most important feature of Massinger's style is a frequent syntactic break in the middle of the line accompanied by a light feminine line ending; the light feminine ending creates an enjambment: the half-line with a light feminine ending runs over onto the next line, thus effacing the division of Massinger's texts into lines. This feature makes Massinger's verse sound even more like prose.

\section{References}

Gasparov, Mikhail Leonovich 1974. Sovremennyj russkij stikh. Metrika i ritmika. Moskva: Nauka.

Jackson, MacDonald P. 2015. Ants Oras and the Analysis of Early Modern English Dramatic Verse. In: Studia Metrica et Poetica 2(2), 48-57.

https://doi.org/10.12697/smp.2015.2.2.04

Kazartsev, Evgeny Vladimirovich 2015. Vvedenie v sravnitel'noe stikhovedenie: metody i osnovy analiza. Sankt-Petersburg: Filologicheskij fakul'tet Sankt-Peterburgskogo gosudarstvennogo universiteta.

Kazartsev, Evgeny Vladimirovich 2017. Sravnitel'noe stikhovedenie: metrika i ritmika. Sankt-Petersburg: Izdatel'stvo RGPU im. A. I. Gertsena.

Kolmogorov, Andrei Nikolaevich; Prokhorov, Aleksandr Vladimirovich 2015 [1968]. K osnovam russkoj klassicheskoj metriki. In: Kolmogorov, Andrei Nikolaevich 
2015. Trudy po stikhovedeniju. Ed. by Prokhorov, Aleksandr Vladimirovich. Moskva: MTsNMO, 109-135.

Kolmogorov, Andrei Nikolaevich; Prokhorov, Aleksandr Vladimirovich 2015 [1985]. Model' ritmicheskogo stroenija russkoj rechi, prisposoblennaja k izucheniju metriki klassicheskogo russkogo stikha. In: Kolmogorov, Andrei Nikolaevich 2015. Trudy po stikhovedeniju. Ed. by Prokhorov, Aleksandr Vladimirovich. Moskva: MTsNMO, 163-180.

Oliphant, Ernest H. C. 1927. The Plays of Beaumont and Fletcher. An Attempt to Determine Their Respective Shares and the Shares of Others. New Haven: Yale University Press.

Oras, Ants 1953. "Extra Monosyllables" in Henry VIII and the Problem of Authorship. In: Journal of English and Germanic Philology 52(2), 198-213. https://www.jstor.org/stable/27713526

Oras, Ants 1960. Pause Patterns in Elizabethan and Jacobean Drama (University of Florida Monographs, Humanities 3). Gainesville, FL: University of Florida Press.

Suckling, John. 1874. The Poems, Plays and Other Remains. London: Lank \& William Kerslake.

Tarlinskaja, Marina 1984. "Rhythmical Differentiation of Shakespeare’s Dramatis Personae". Language and Style 17(4), 287-301.

Tarlinskaja, Marina 1987a. Rhythm and Meaning: "Rhythmical Figures" in English Iambic Pentameter, Their Grammar, and Their Link with Semantics. In: Style 21(1), 1-35. https://www.jstor.org/stable/42945629

Tarlinskaja, Marina 1987b. Shakespeare's Verse: Iambic Pentameter and the Poet's Idiosyncrasies. New York: Peter Lang.

Tarlinskaja, Marina 2002. Verse Text: Its Meter and Its Oral Rendition. In: Christoph Küper (ed.), Meter, Rhythm and Performance - Metrum, Rhythmus, Performanz: Proceedings of the International Conference on Meter, Rhythm and Performance, held in May 1999 at Vechta. Bern, Berlin, [etc.]: Peter Lang, 39-55.

Tarlinskaja, Marina 2014. Shakespeare and the Versification of English Drama 15611642. Farnham, Surrey and Burlington, VT: Ashgate.

Zhirmunsky, Viktor Maksimovich 1925. Vvedenie v metriku: Teorija stikha. Leningrad: Academia.

Zhirmunsky, Viktor Maksimovich 1966. Introduction to Metrics: The Theory of Verse. Translated from the Russian by C. F. Brown. Edited with an introduction by Edward Stankiewicz and Walter N. Vickery. London, The Hague, Paris: Mouton. 


\section{Addenda}

Table 1. Stressing on strong syllabic positions (in \% from all lines)

\begin{tabular}{|c|c|c|c|c|c|c|}
\hline \multirow[t]{2}{*}{ Author, work } & \multirow[t]{2}{*}{ Date } & \multicolumn{5}{|c|}{ Strong Syllabic Positions } \\
\hline & & 2 & 4 & 6 & 8 & 10 \\
\hline Kyd, The Spanish Tragedy & $1586-87$ & 56.7 & 87.2 & 69.2 & 75.7 & 82.8 \\
\hline Shakespeare, Romeo and Juliet & 1594-95 & 65.7 & 87.2 & 68.3 & 75.6 & 88.5 \\
\hline Shakespeare, Henry $V$ & $1598-99$ & 63.5 & 81.7 & 70.8 & 71.9 & 86.9 \\
\hline Shakespeare, The Tempest & $1610-11$ & 67.9 & 80.1 & 77.7 & 70.4 & 87.6 \\
\hline Fletcher, Valentinian & $1610-14$ & 68.8 & 86.6 & 84.9 & 74.3 & 95.2 \\
\hline Fletcher, Monsieur Thomas & $1610-14$ & 76.0 & 82.9 & 82.3 & 73.3 & 96.0 \\
\hline Fletcher, Bonduca & $<1613$ & 67.8 & 85.2 & 82.3 & 75.5 & 94.1 \\
\hline Fletcher, The Island Princess & $1619-21$ & 71.1 & 79.3 & 81.2 & 67.7 & 96.3 \\
\hline Massinger, The Maid of Honor & $1620-23$ & 73.8 & 75.9 & 74.9 & 63.9 & 90.1 \\
\hline Massinger, A New Way & 1625 & 73.7 & 81.7 & 76.6 & 68.0 & 94.7 \\
\hline Massinger, The City Madam & 1632 & 74.5 & 83.3 & 76.8 & 65.6 & 93.7 \\
\hline Shakespeare, Henry VIII & $1612-13$ & 68.3 & 80.2 & 77.6 & 68.6 & 88.1 \\
\hline Fletcher, Henry VIII & & 63.7 & 82.4 & 75.1 & 71.5 & 91.6 \\
\hline Shakespeare, Noble Kinsmen & 1613 & 71.0 & 81.1 & 78.4 & 71.8 & 87.6 \\
\hline Fletcher, Noble Kinsmen & & 64.8 & 82.2 & 78.8 & 69.5 & 92.5 \\
\hline Fletcher, The Maid's Tragedy & 1611 & 58.9 & 82.5 & 79.3 & 70.2 & 95.2 \\
\hline Beaumont, The Maid's Tragedy & & 70.8 & 84.8 & 70.1 & 70.8 & 93.1 \\
\hline Fletcher, The False One & 1620 & 68.7 & 84.2 & 79.1 & 69.8 & 90.0 \\
\hline Massinger, The False One & & 72.4 & 76.3 & 75.4 & 64.2 & 92.0 \\
\hline Fletcher, The Maid in the Mill & 1623 & 68.6 & 90.8 & 80.2 & 73.7 & 95.9 \\
\hline Rowley, The Maid in the Mill & & 72.1 & 86.5 & 73.5 & 73.5 & 90.7 \\
\hline
\end{tabular}


Table 2. Strong syntactic breaks after syllables 2-11 (in \% of all lines)

\begin{tabular}{|c|c|c|c|c|c|c|c|c|c|c|}
\hline \multirow[t]{2}{*}{ Author, Work } & \multicolumn{10}{|c|}{ Syllabic Positions } \\
\hline & 2 & 3 & 4 & 5 & 6 & 7 & 8 & 9 & 10 & 11 \\
\hline Kyd, The Spanish Tragedy & 11.9 & 4.4 & 22.7 & 9.3 & 6.9 & 2.6 & 1.7 & 0.7 & 89.1 & 1.3 \\
\hline Shakespeare, Romeo and Juliet & 10.2 & 4.8 & 25.7 & 13.0 & 14.0 & 4.4 & 3.4 & 1.6 & 81.9 & 5.4 \\
\hline Shakespeare, Henry $V$ & 6.6 & 3.2 & 14.3 & 11.1 & 13.5 & 6.8 & 2.8 & 62.5 & 15.8 & 21.8 \\
\hline Shakespeare, Tempest & 7.2 & 2.7 & 17.0 & 15.8 & 30.0 & 17.7 & 13.2 & 8.1 & 35.9 & 22.1 \\
\hline Fletcher, Valentinian & 6.2 & 3.4 & 16.0 & 10.3 & 18.4 & 26.8 & 14.3 & 4.1 & 20.7 & 65.9 \\
\hline Fletcher, Monsieur Thomas & 7.4 & 7.2 & 19.3 & 14.2 & 23.5 & 28.8 & 15.2 & 3.2 & 13.6 & 70.1 \\
\hline Fletcher, Bonduca & 8.6 & 5.1 & 18.0 & 15.5 & 23.9 & 29.3 & 18.0 & 8.0 & 25.3 & 57.6 \\
\hline Fletcher, The Island Princess & 5.1 & 3.8 & 15.4 & 10.4 & 25.7 & 17.8 & 11.3 & 4.4 & 12.9 & 75.6 \\
\hline Massinger, The Maid of Honour & 6.2 & 5.3 & 13.6 & 17.8 & 20.9 & 25.2 & 13.8 & 5.2 & 23.0 & 29.8 \\
\hline Massinger, A New Way to Pay & 7.4 & 4.7 & 17.5 & 20.8 & 20.7 & 21.8 & 12.9 & 3.3 & 30.1 & 39.6 \\
\hline Massinger, The City Madam & 4.2 & 4.7 & 12.4 & 21.3 & 21.0 & 21.3 & 11.0 & 3.7 & 18.5 & 40.7 \\
\hline Shakespeare, Henry VIII & 5.7 & 2.7 & 12.9 & 14.5 & 28.0 & 23.2 & 13.6 & 6.6 & 35.6 & 18.8 \\
\hline Fletcher, Henry VIII & 9.8 & 4.5 & 17.3 & 16.5 & 20.5 & 24.6 & 15.7 & 4.0 & 30.9 & 48.1 \\
\hline Shakespeare, Kinsmen & 6.1 & 1.8 & 15.0 & 14.9 & 29.8 & 22.3 & 12.1 & 6.6 & 29.4 & 17.8 \\
\hline Fletcher, Kinsmen & 5.6 & 7.2 & 18.4 & 17.7 & 22.4 & 25.1 & 13.8 & 5.4 & 28.6 & 49.9 \\
\hline Fletcher. The Maid's Tragedy & 6.5 & 3.8 & 13.2 & 18.3 & 21.0 & 25.8 & 15.6 & 5.1 & 32.5 & 45.1 \\
\hline Beaumont, The Maid's Tragedy & 9.0 & 7.3 & 23.4 & 19.2 & 28.5 & 11.5 & 8.7 & 3.1 & 54.7 & 11.7 \\
\hline Fletcher, The False One & 6.7 & 3.2 & 19.1 & 14.0 & 26.6 & 16.2 & 12.7 & 3.4 & 15.4 & 76.5 \\
\hline Massinger, The False One & 6.3 & 4.6 & 15.4 & 17.0 & 21.8 & 22.2 & 9.4 & 1.8 & 31.5 & 31.6 \\
\hline Fletcher, The Maid in the Mill & 9.5 & 4.7 & 26.1 & 18.3 & 29.9 & 15.4 & 25.1 & 6.2 & 16.3 & 77.9 \\
\hline Rowley, The Maid in the Mill & 8.3 & 8.4 & 19.6 & 15.3 & 25.2 & 17.3 & 9.0 & 5.1 & 37.9 & 39.3 \\
\hline
\end{tabular}




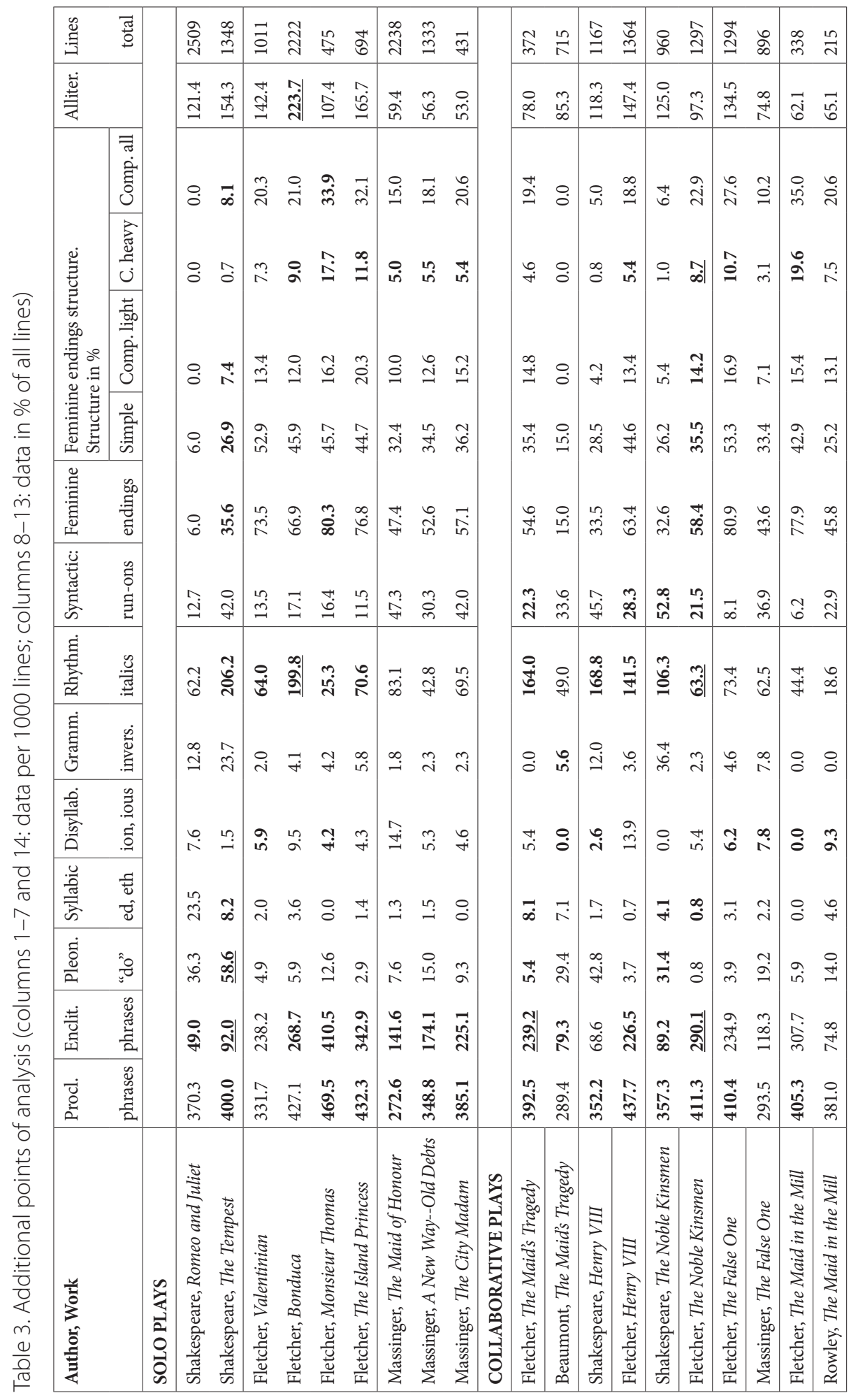

